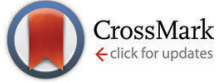

Cite this: Phys. Chem. Chem. Phys., 2015, 17, 23909

Received 22nd April 2015, Accepted 5th August 2015 DOI: $10.1039 / c 5 c p 02361 k$

www.rsc.org/pccp

\title{
Surface structured platinum electrodes for the electrochemical reduction of carbon dioxide in imidazolium based ionic liquids
}

\author{
Florin A. Hanc-Scherer, ${ }^{a}$ Miguel A. Montiel, ${ }^{b}$ Vicente Montiel, ${ }^{b}$ Enrique Herrero ${ }^{b}$ \\ and Carlos M. Sánchez-Sánchez ${ }^{\star c d}$
}

\begin{abstract}
The direct $\mathrm{CO}_{2}$ electrochemical reduction on model platinum single crystal electrodes $\mathrm{Pt}(h k l)$ is studied in $\left[\mathrm{C}_{2} \mathrm{mim}^{+}\right]\left[\mathrm{NTf}_{2}{ }^{-}\right]$, a suitable room temperature ionic liquid (RTIL) medium due to its moderate viscosity, high $\mathrm{CO}_{2}$ solubility and conductivity. Single crystal electrodes represent the most convenient type of surface structured electrodes for studying the impact of RTIL ion adsorption on relevant electrocatalytic reactions, such as surface sensitive electrochemical $\mathrm{CO}_{2}$ reduction. We propose here based on cyclic voltammetry and in situ electrolysis measurements, for the first time, the formation of a stable adduct $\left[\mathrm{C}_{2} \mathrm{mimH}-\mathrm{CO}_{2}{ }^{-}\right]$by a radical-radical coupling after the simultaneous reduction of $\mathrm{CO}_{2}$ and $\left[\mathrm{C}_{2} \mathrm{mim}^{+}\right]$. It means between the $\mathrm{CO}_{2}$ radical anion and the radical formed from the reduction of the cation $\left[\mathrm{C}_{2} \mathrm{mim}^{+}\right]$ before forming the corresponding electrogenerated carbene. This is confirmed by the voltammetric study of a model imidazolium-2-carboxylate compound formed following the carbene pathway. The formation of that stable adduct $\left[\mathrm{C}_{2} \mathrm{mimH}-\mathrm{CO}_{2}^{-}\right]$blocks $\mathrm{CO}_{2}$ reduction after a single electron transfer and inhibits $\mathrm{CO}_{2}$ and imidazolium dimerization reactions. However, the electrochemical reduction of $\mathrm{CO}_{2}$ under those conditions provokes the electrochemical cathodic degradation of the imidazolium based RTIL. This important limitation in $\mathrm{CO}_{2}$ recycling by direct electrochemical reduction is overcome by adding a strong acid, $\left[\mathrm{H}^{+}\right]\left[\mathrm{NTf}_{2}{ }^{-}\right]$, into solution. Then, protons become preferentially adsorbed on the electrode surface by displacing the imidazolium cations and inhibiting their electrochemical reduction. This fact allows the surface sensitive electro-synthesis of $\mathrm{HCOOH}$ from $\mathrm{CO}_{2}$ reduction in $\left[\mathrm{C}_{2} \mathrm{mim}^{+}\right]\left[\mathrm{NTf}_{2}{ }^{-}\right]$, with $\mathrm{Pt}(110)$ being the most active electrode studied.
\end{abstract}

\section{Introduction}

Carbon dioxide $\left(\mathrm{CO}_{2}\right)$ emission arising from human activities is considered as a major contributor to the global greenhouse effect. Thus, the $\mathrm{CO}_{2}$ conversion into useful chemical products and/or energy is a critical concern nowadays. ${ }^{1} \mathrm{CO}_{2}$ reduction can yield a large variety of useful products, such as $\mathrm{C}_{1}$ species like carbon monoxide $(\mathrm{CO})$, formic acid $(\mathrm{HCOOH})$, methane $\left(\mathrm{CH}_{4}\right)$ and methanol $\left(\mathrm{CH}_{3} \mathrm{OH}\right)$, or $\mathrm{C}_{2}$ products like oxalic acid $\left(\mathrm{H}_{2} \mathrm{C}_{2} \mathrm{O}_{4}\right)$, ethane $\left(\mathrm{C}_{2} \mathrm{H}_{6}\right)$, ethanol $\left(\mathrm{C}_{2} \mathrm{H}_{5} \mathrm{OH}\right)$, and ethylene $\left(\mathrm{C}_{2} \mathrm{H}_{4}\right)$. Indeed, different alternatives have been studied to transform $\mathrm{CO}_{2}{ }^{2,3}$ which include electro-synthesis of pharmacological or industrial

\footnotetext{
${ }^{a}$ Babes-Bolyai University, Faculty of Chemistry and Chemical Engineering, 11 Arany Janos Street, RO-400028 Cluj-Napoca, Romania

${ }^{b}$ Instituto Universitario de Electroquímica, Universidad de Alicante, Ap. 99, 03080, Alicante, Spain

${ }^{c}$ Sorbonne Universités, UPMC Univ Paris 06, UMR 8235, Laboratoire Interfaces et Systèmes Electrochimiques, F-75005, Paris, France.

E-mail: carlos.sanchez@upmc.fr; Fax: +33 144274074; Tel: +33 144274158

${ }^{d}$ CNRS, UMR 8235, LISE, F-75005, Paris, France
}

valuable compounds, ${ }^{4,5}$ chemical reduction by heterogeneous catalysis, ${ }^{6,7}$ photocatalytic conversion, ${ }^{8,9}$ and electrochemical reduction, which comprises molecular catalysed electrochemical reduction of $\mathrm{CO}_{2}{ }^{10-12}$ and direct electrocatalytic reduction of $\mathrm{CO}_{2}{ }^{12-16}$

In particular, direct electrochemical conversion and recycling of $\mathrm{CO}_{2}$ represents a promising pathway, where product selectivity strongly depends on two main factors; (i) the electrode material employed ${ }^{13,15}$ and (ii) the nature of the solvent (aqueous/non-aqueous) supporting electrolyte system. ${ }^{14,17}$ The type of solvent is an important factor for the electrochemical $\mathrm{CO}_{2}$ reduction, since most studies in aqueous media present some difficulties in controlling the concomitant side reaction of hydrogen evolution, which takes place at similar thermodynamic potentials. ${ }^{18}$ On the other hand, conventional aprotic non-aqueous media, such as dimethyl sulfoxide (DMSO), $N, N$ dimethyl formamide (DMF) or acetonitrile (AN), present several advantages, since they avoid hydrogen evolution and present high $\mathrm{CO}_{2}$ solubility (see Table 1). However, their main drawbacks are their high toxicity and volatility, the costly electrolytes 
Table $1 \mathrm{CO}_{2}$ solubility and viscosity of different solvents at $298 \mathrm{~K}$

\begin{tabular}{lll}
\hline Solvent & Solubility $(\mathrm{M})^{26-28}$ & Viscosity $(\mathrm{cP})^{21}$ \\
\hline $\mathrm{H}_{2} \mathrm{O}$ & 0.033 & $(0-1)$ \\
Acetonitrile (AN) & 0.279 & $(0-1)$ \\
{$\left[\mathrm{C}_{2} \mathrm{mim}^{+}\right]\left[\mathrm{NTf}_{2}^{-}\right]$} & 0.130 & 29 \\
\hline
\end{tabular}

employed and the difficulty in recycling the solvent and the electrolyte. A special category of non-aqueous solvents is comprised of room-temperature ionic liquids (RTILs), which have been pointed out as the most suitable solvents for carrying on the future developments in electrochemistry. ${ }^{19}$ RTILs are commonly defined as materials composed entirely of organic cations and organic or inorganic anions, which melt at or below $100{ }^{\circ} \mathrm{C} .{ }^{20}$ This low melting point is their main difference versus molten salts, which require high working temperatures. Moreover, RTILs present a unique set of properties, which includes suitable ionic conductivity, high thermal stability, negligible vapor pressure and non-flammability. ${ }^{21}$ All these properties allow RTILs to perform simultaneously the role of a solvent and an electrolyte in electrochemical applications and rule out any safety concern. RTILs comprise a large number of different solvents, but depending on whether the cation employed presents an available proton or not, two main subdivisions are possible; protic ionic liquids (PILs) ${ }^{22}$ and aprotic ionic liquids (AILs). ${ }^{23}$ Imidazolium based cations represent an example of that, since depending on the degree of substitution within the imidazolium ring they belong either to the PILs (1,2-dialkyl-imidazoliums) or AILs (1,3-dialkyl-imidazoliums and 1,2,3-trialkylimidazoliums). One of the major drawbacks of RTILs in electrochemical applications is their high viscosity, since this produces low diffusion of the electroactive species and limits the maximum current density in the process. The viscosity of RTILs varies with the type of cation and anion. In particular, 1,3-dialkyl-imidazolium $\left[\mathrm{C}_{n} \mathrm{mim}^{+}\right]$cations are one of the most common RTIL cations for electrochemical purposes, since they exhibit both high ionic conductivity and low viscosity values in comparison with all other RTIL cations. Conductivity and viscosity are inversely related, the alkyl chain length $(n)$ of the imidazolium cation being responsible for limiting both. For this reason, the short alkyl chain $(n=2)$ cation, 1-ethyl-3methylimidazolium $\left[\mathrm{C}_{2} \mathrm{mim}^{+}\right]$, presents both low viscosity and high conductivity values and is selected as a suitable solvent in the present work. This cation is combined with an asymmetric anion like bis(trifluoromethylsulfonyl)imide $\left[\mathrm{NTf}_{2}{ }^{-}\right]$, which also presents one of the lowest viscosity values among the most common anions in RTILs. ${ }^{21}$ Thus, $\left[\mathrm{C}_{2} \mathrm{mim}^{+}\right]\left[\mathrm{NTf}_{2}{ }^{-}\right]$exhibits a low viscosity $(29 \mathrm{cP} \text { at } 298 \mathrm{~K})^{21}$ combined with a high solubility of $\mathrm{CO}_{2}$, comparable to the one exhibited in non-aqueous solvents (see Table 1). In principle, the gas solubility in RTILs is mainly controlled by the nature of the RTIL anion. Thus, a strong interaction of $\mathrm{CO}_{2}$ with the RTIL anion is the best indicator of $\mathrm{CO}_{2}$ solubility, with $\left[\mathrm{NTf}_{2}{ }^{-}\right]$being the anion presenting one of the greatest affinities for $\mathrm{CO}_{2} \cdot{ }^{24}$ Moreover, this hydrophobic anion allows $\left[\mathrm{C}_{2} \mathrm{mim}^{+}\right]\left[\mathrm{NTf}_{2}{ }^{-}\right]$to be water immiscible, which is an advantage, since the water solubility in
$\left[\mathrm{C}_{2} \mathrm{mim}^{+}\right]\left[\mathrm{NTf}_{2}^{-}\right]$limits its available electrochemical window (3400 ppm $\mathrm{H}_{2} \mathrm{O}$ under atmospheric conditions at $298 \mathrm{~K}$ ). ${ }^{25}$ For all those reasons, its moderate viscosity, high $\mathrm{CO}_{2}$ solubility and conductivity, we propose herein $\left[\mathrm{C}_{2} \mathrm{mim}^{+}\right]\left[\mathrm{NTf}_{2}{ }^{-}\right]$as the suitable RTIL for studying the direct $\mathrm{CO}_{2}$ electrochemical reduction on model surfaces such as platinum single crystal electrodes.

After solvent selection, the other key point controlling the product selectivity in the electrochemical reduction of $\mathrm{CO}_{2}$ is the electrocatalytic activity of the electrode material. Thus, $\mathrm{CO}_{2}$ interacts with the metal surface in the presence of $\left[\mathrm{C}_{2} \mathrm{mim}^{+}\right]\left[\mathrm{NTf}_{2}{ }^{-}\right]$ionic pairs. In spite of that, only a few reports have approached that interaction pointing out structures such as the checkerboard-type sandwich arrangement with imidazolium cations and $\left[\mathrm{NTf}_{2}{ }^{-}\right]$anions absorbed alternatively next to each other on the electrode substrate. ${ }^{29,30}$ For this reason, single crystal electrodes represent the most convenient type of surface structured electrodes for studying the impact of RTIL ion adsorption on electrocatalytic reactions, since they provide site distribution control at the electrode surface. In particular, we propose studying the electrocatalytic activity for $\mathrm{CO}_{2}$ reduction as a function of surface sites using Pt single crystal $(\mathrm{Pt}(h k l))$ electrodes, since it has been already proved that imidazolium cation adsorption is a surface-sensitive process ${ }^{31}$ and this may drastically affect the $\mathrm{CO}_{2}$ reduction activity at the electrode.

Electrochemical reduction of $\mathrm{CO}_{2}$ on $\mathrm{Pt}(h k l)$ electrodes in acid aqueous solution takes place at potentials where hydrogen adsorption also occurs. Moreover, this reaction presents high sensitivity towards the surface site available at the electrode surface by displaying low activity at highly ordered $\mathrm{Pt}(111)$ and Pt(100), but high activity at Pt(110) kinked and stepped surfaces. ${ }^{32-34}$ More recently, several $\mathrm{Pt}(h k l)$ electrodes selectively modified with adsorbed adatoms $(\mathrm{Bi}, \mathrm{Te}$ and $\mathrm{Sb}$ ) have also exhibited high catalytic activity for $\mathrm{CO}_{2}$ reduction in buffered neutral aqueous media. ${ }^{16}$ In contrast, electrocatalytic studies for $\mathrm{CO}_{2}$ reduction in different RTILs have been only reported using Pt polycrystalline surfaces. ${ }^{35,36}$ But, as far as the author's knowledge, the electrochemical reduction of $\mathrm{CO}_{2}$ on $\mathrm{Pt}(h k l)$ electrodes in a RTIL medium has not been reported yet. Only a few articles devoted to studying conducting polymers ${ }^{37}$ or electrochemical hydrogen ${ }^{38,39}$ and carbon monoxide ${ }^{40}$ oxidation reactions on $\mathrm{Pt}(h k l)$ electrodes in different RTILs can be found in the literature.

It is well established in the electrocatalytic $\mathrm{CO}_{2}$ reduction reaction that the first reaction step consists of the $\mathrm{CO}_{2}$ adsorption at the electrode surface and the subsequent electron transfer to form the corresponding radical-anion $\left(\mathrm{CO}_{2}{ }^{-}\right)$, as described in eqn (1), where $\mathrm{M}$ stands for the metal electrocatalyst. ${ }^{15}$ Moreover, in liquid electrolytes it has been also described that $\mathrm{CO}_{2}$ may form adducts by coupling with different anions present in solution, such as $\mathrm{BF}_{3} \mathrm{Cl}^{-}$or 1-isoquinolinecarboxylic acid. ${ }^{35,41}$ The formation of those adducts weakens the $\mathrm{C}=\mathrm{O}$ bond and makes the reduction of $\mathrm{CO}_{2}$ more favorable. For this reason, it has been recently suggested that a convenient way to lower the potential necessary for achieving the first electron transfer for $\mathrm{CO}_{2}$ 
reduction is decreasing the $\mathrm{CO}_{2}{ }^{--}$free energy of formation. This is achieved by forming a complex between the $\mathrm{CO}_{2}{ }^{--}$and an imidazolium based cation such as $\left[\mathrm{C}_{2} \mathrm{mim}^{+}\right]$, since this will help to decrease the overall energy barrier. ${ }^{42}$ The formation of such a complex has been proposed to be mainly responsible for the highly active ionic-liquid mediated electrochemical conversion of $\mathrm{CO}_{2}$ into $\mathrm{CO}$ at low overpotentials in a mixture of water and an imidazolium based ionic liquid. After the first electron transfer forms $\mathrm{CO}_{2}{ }^{\bullet-}$, several possible reaction pathways may be followed depending on the solvent conditions. They can be mainly divided into those that need the abundant presence of available protons and a second electron transfer, which may form either $\mathrm{HCOOH}$ (eqn (2)), if the proton is attached to the $\mathrm{CO}_{2}{ }^{\bullet-}$, or CO (eqn (3)), if the proton removes one of the oxygen atoms within the $\mathrm{CO}_{2}{ }^{--}$. In contrast, if protons are not available, as usually happens in nonaqueous systems, the dimerization reaction mainly produces $\mathrm{C}_{2} \mathrm{O}_{4}{ }^{2-}$ (eqn (4)).

$$
\begin{gathered}
\mathrm{M}+\mathrm{CO}_{2}+\mathrm{e}^{-} \rightarrow \mathrm{M} \cdot \mathrm{CO}_{2}{ }^{--} \\
\mathrm{CO}_{2}+2 \mathrm{H}^{+}+2 \mathrm{e}^{-} \rightarrow \mathrm{HCOOH} \\
\mathrm{CO}_{2}+2 \mathrm{H}^{+}+2 \mathrm{e}^{-} \rightarrow \mathrm{CO} \\
2 \mathrm{CO}_{2}+2 \mathrm{e}^{-} \rightarrow \mathrm{C}_{2} \mathrm{O}_{4}{ }^{2-}
\end{gathered}
$$

\section{Experimental}

\section{Chemicals and electrodes}

The ionic liquid 1-ethyl-3-methylimidazolium bis(trifluoromethylsulfonyl)imide $\left[\mathrm{C}_{2} \mathrm{mim}^{+}\right]\left[\mathrm{NTf}_{2}^{-}\right] 98 \%$ was supplied by Aldrich. This was used straight from the supplier, and its water content was minimized by maintaining it under an argon atmosphere within a silica gel container. 1,3-Dimethylimidazolium-2-carboxylate $\left(\mathrm{C}_{6} \mathrm{H}_{8} \mathrm{~N}_{2} \mathrm{O}_{2}\right)>80 \%$ was supplied by Aldrich. Bis(trifluoromethanesulfonyl)amine $\left[\mathrm{H}^{+}\right]\left[\mathrm{NTf}_{2}{ }^{-}\right]$ 95\% supplied by Aldrich is a strong acid, which is fully dissociated when dissolved in $\left[\mathrm{C}_{2} \mathrm{mim}^{+}\right]\left[\mathrm{NTf}_{2}{ }^{-}\right]$. Ar and $\mathrm{CO}_{2}$ $\geq 99.998$ purity supplied by Air Liquide were used in all experiments.

Pt polycrystalline electrodes and $\mathrm{Pt}(100), \mathrm{Pt}(110)$ and $\mathrm{Pt}(111)$ single crystal electrodes ${ }^{43}$ were made from single crystal platinum beads (2.5 $\mathrm{mm}$ in diameter), obtained by fusion and subsequent slow crystallization of a $99.999 \%$ platinum wire (0.5 $\mathrm{mm}$ in diameter). For the $\mathrm{Pt}(h k l)$ electrodes, after careful cooling, the resulting single crystal beads were oriented, cut and polished following the procedure described by Clavilier et al. in ref. 44. Prior to any experiment, the $\mathrm{Pt}(h k l)$ electrodes were air flame-annealed ${ }^{45}$ for $20-30 \mathrm{~s}$, cooled in a reductive atmosphere $\left(\mathrm{H}_{2}\right.$ : Ar, ratio $\left.1: 3 \mathrm{v} / \mathrm{v}\right)$, quenched in $\left[\mathrm{C}_{2} \mathrm{mim}^{+}\right]\left[\mathrm{NTf}_{2}{ }^{-}\right]$in equilibrium with that atmosphere and finally immersed in the electrochemical cell under potential controlled conditions using a meniscus configuration.

\section{Electrochemical characterization}

A one compartment electrochemical glass cell with a threeelectrode configuration at room temperature and atmospheric pressure was employed for performing cyclic voltammetry experiments. All measurements were made using a computer controlled Autolab PGSTAT30 potentiostat driven by NOVA software. The electrocatalytic activity for the $\mathrm{CO}_{2}$ reduction reaction was studied in the presence and the absence of a proton source using $\left[\mathrm{C}_{2} \mathrm{mim}^{+}\right]\left[\mathrm{NTf}_{2}^{-}\right]$as a solvent supporting electrolyte system. Prior to any experiment, the electrochemical cell was dried in hot air and Ar gas was flowed into the empty cell in order to remove any trace of water. A small volume of $\left[\mathrm{C}_{2} \mathrm{mim}^{+}\right]\left[\mathrm{NTf}_{2}{ }^{-}\right](\sim 3.5 \mathrm{~mL})$ was used in each experiment and this was saturated with either $\mathrm{Ar}$ or $\mathrm{CO}_{2}$ gas for at least $20 \mathrm{~min}$ before each experiment. A platinum wire, $0.5 \mathrm{~mm}$ diameter, was used as a counter electrode and the reference electrode was also another Pt wire (quasi-reference electrode). This reference was placed inside of a glass cylinder with a glass frit separator at the bottom and immersed in a solution identical to the one initially used within the electrochemical cell. This is necessary to isolate the quasi-reference electrode as much as possible from potential chemical interference derived from the faradic processes occurring in solution during cyclic voltammetry. ${ }^{46}$ This is a crucial issue here, since the highly negative potentials reached in voltammetries may provoke $\mathrm{H}_{2}$ evolution to some extent, which in contact with the Pt wire quasi-reference electrode may modify its open circuit potential and subsequently, the reference potential in the electrochemical cell.

\section{Results and discussion}

RTILs generally exhibit a wide electrochemical potential window. But, in the absence of any other electroactive species, they may undergo electrochemical degradation. The electrochemical stability of the imidazolium cation limits the cathodic polarization window, since the cation $\left[\mathrm{C}_{2} \mathrm{mim}^{+}\right]$may be reduced to form the corresponding radical $\left[\mathrm{C}_{2} \mathrm{mim}^{\bullet}\right]$. The carbon atom between the two nitrogen atoms in the imidazolium ring is the most electron deficient atom and is hence the most active site for reduction as shown in eqn (5). ${ }^{47}$

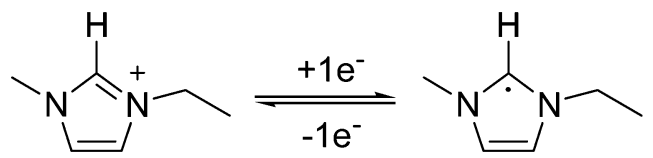

Fig. 1 shows the cyclic voltammogram of $\left[\mathrm{C}_{2} \mathrm{mim}^{+}\right]\left[\mathrm{NTf}_{2}{ }^{-}\right]$ between -1.3 and $1.0 \mathrm{~V}$, where a well-defined quasi-reversible reduction-oxidation response is observed on the $\mathrm{Pt}(111)$ electrode, which proves high stability of the radical formed $\left[\mathrm{C}_{2} \mathrm{mim}^{\bullet}\right]$, since this may be oxidized back to the initial cation. This behavior is observed in both argon and $\mathrm{CO}_{2}$ saturated $\left[\mathrm{C}_{2} \mathrm{mim}^{+}\right]\left[\mathrm{NTf}_{2}{ }^{-}\right]$. Similar quasi-reversible voltammograms on the Pt(111) electrode were already reported in the literature using several imidazolium-based RTILs. ${ }^{38}$ However, if the cathodic limit of potential is extended up to $-3.1 \mathrm{~V}$, (Fig. 2), this quasi-reversible behaviour disappears. This has been already assigned in the literature to the formation of the corresponding imidazolium 


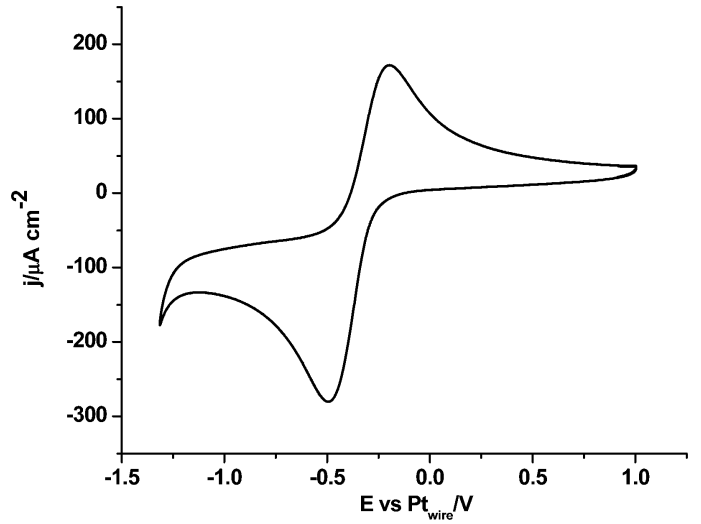

Fig. 1 Cyclic voltammogram of Pt(111) in argon saturated $\left[\mathrm{C}_{2} \mathrm{mim}^{+}\right]\left[\mathrm{NTf}_{2}{ }^{-}\right]$. Scan rate: $0.05 \mathrm{~V} \mathrm{~s}^{-1}$.

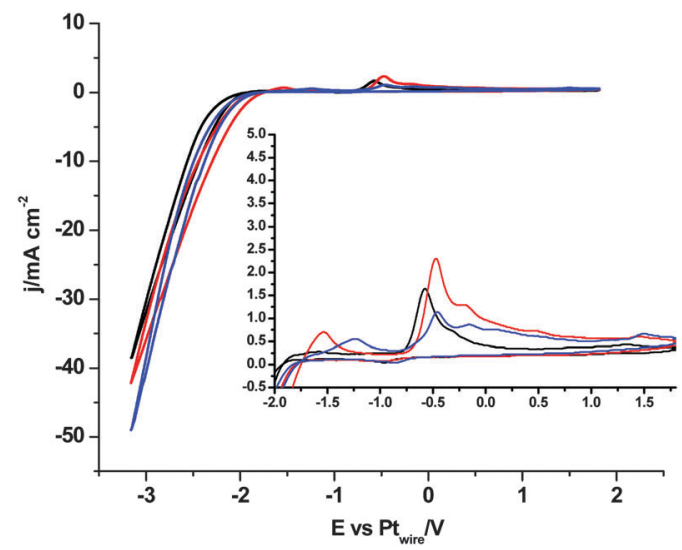

Fig. 2 Cyclic voltammograms of Pt(111), black plot, Pt(110), red plot, and $\mathrm{Pt}(100)$, blue plot, in argon saturated $\left[\mathrm{C}_{2} \mathrm{mim}^{+}\right]\left[\mathrm{NTf}_{2}{ }^{-}\right]$. Scan rate: $0.05 \mathrm{~V} \mathrm{~s}^{-1}$

carbene by electrochemical reduction and simultaneous hydrogen abstraction following eqn $(6)^{38}$ or $(7) .{ }^{47-49}$<smiles></smiles>

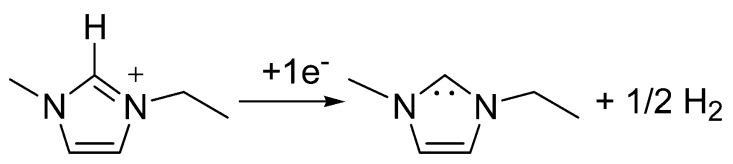

Furthermore, it is possible to observe in Fig. 2 the $\mathrm{H}_{2}$ evolution reaction in all three low index planes of platinum. Oxidation of the newly formed $\mathrm{H}_{2}$ can be more clearly observed on $\mathrm{Pt}(100)$ and $\mathrm{Pt}(110)$ electrodes in the reverse potential scan (inset of Fig. 2, oxidation peak between -1.7 and $-1.0 \mathrm{~V}$ ). In contrast, the oxidation peak shown at $-0.5 \mathrm{~V}$ in Fig. 2 has been assigned in the literature ${ }^{49}$ to the oxidation of the electrogenerated imidazolium carbene back to the initial cation. In particular, Feroci and co-workers have proposed the use of those electrogenerated imidazolium carbenes as a synthetic tool for capturing $\mathrm{CO}_{2}$ and forming an imidazolium-2-carboxylate product by a coupling reaction between the electrogenerated carbene and $\mathrm{CO}_{2}$ as described in eqn (8). ${ }^{49,50}$ This reported reaction takes place outside the electrochemical cell, by $\mathrm{CO}_{2}$ saturation of $\left[\mathrm{C}_{4} \mathrm{mim}^{+}\right]\left[\mathrm{BF}_{4}{ }^{-}\right]$after performing a galvanostatic reductive electrolysis on glassy carbon, $\mathrm{Pt}$, Pd or $\mathrm{Au}$ for electrogenerating the corresponding imidazolium carbene. This $\mathrm{CO}_{2}$ coupling reaction is reported to produce a diminution in the oxidation current at $-0.5 \mathrm{~V}$ assigned to the carbene oxidation back to the initial cation when the voltammogram in the $\mathrm{CO}_{2}$ presence is compared with the one in the $\mathrm{CO}_{2}$ absence, since most of the carbene is consumed by reaction with $\mathrm{CO}_{2}$. For this reason, the imidazolium-2-carboxylate product formed in eqn (8) is reported as an electroinactive adduct, ${ }^{49}$ which may only give back $\mathrm{CO}_{2}$ and imidazolium cations by heating induced decomposition.

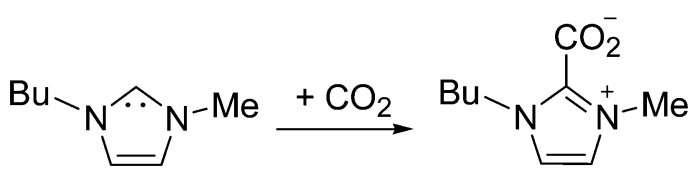

In contrast, when we compare the cyclic voltammograms reaching $-3.1 \mathrm{~V}$, in the absence of $\mathrm{CO}_{2}$ in $\left[\mathrm{C}_{2} \mathrm{mim}^{+}\right]\left[\mathrm{NTf}_{2}{ }^{-}\right]$ (Fig. 2) and in $\mathrm{CO}_{2}$ saturated $\left[\mathrm{C}_{2} \mathrm{mim}^{+}\right]\left[\mathrm{NTf}_{2}{ }^{-}\right]$(Fig. 3), the oxidation peak current at $-0.5 \mathrm{~V}$ increases for $\mathrm{Pt}(110)$ and $\operatorname{Pt}(100)$ in the presence of $\mathrm{CO}_{2}$, and decreases only for Pt(111), which points out that different processes are taking place. Firstly, $\mathrm{H}_{2}$ evolution is inhibited in all three $\mathrm{Pt}(h k l)$ electrodes when $\mathrm{CO}_{2}$ is present in the electrochemical cell, since no subsequent oxidation current peaks are displayed in the reverse potential scan between -1.7 and $-1.0 \mathrm{~V}$ (see the inset of Fig. 3). Secondly, the comparison between the insets in Fig. 2 and 3 shows an important increase in the oxidation peak current displayed at $-0.5 \mathrm{~V}$ for $\mathrm{Pt}(110)$ and $\mathrm{Pt}(100)$ electrodes when $\mathrm{CO}_{2}$ is present, but none for $\mathrm{Pt}(111)$. These facts indicate that the process taking place at potentials more negative than $-2.0 \mathrm{~V}$ is not only the $\left[\mathrm{C}_{2} \mathrm{mim}^{+}\right]$reduction following eqn (6) or (7). In fact, this corresponds to the simultaneous reduction of $\left[\mathrm{C}_{2} \mathrm{mim}^{+}\right]$and $\mathrm{CO}_{2}$ species on the $\mathrm{Pt}(100)$ and $\mathrm{Pt}(110)$ electrodes, which produces the formation of a new stable species $\left[\mathrm{C}_{2} \mathrm{mimH}-\mathrm{CO}_{2}^{-}\right]$by a radical-radical coupling of both reaction

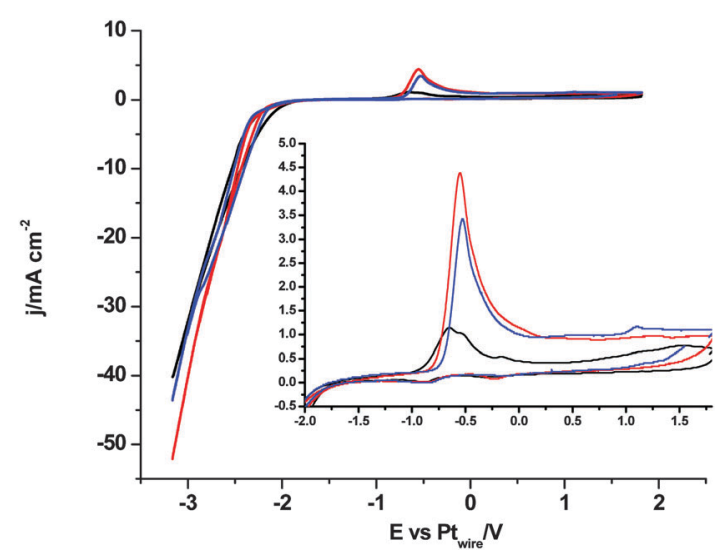

Fig. 3 Cyclic voltammograms of Pt(111), black plot, Pt(110), red plot, and $\mathrm{Pt}(100)$, blue plot, in $\mathrm{CO}_{2}$ saturated $\left[\mathrm{C}_{2} \mathrm{mim}^{+}\right]\left[\mathrm{NTf}_{2}{ }^{-}\right]$. Scan rate: $0.05 \mathrm{~V} \mathrm{~s}^{-1}$. 
products formed following eqn (1) $\left(\mathrm{CO}_{2}{ }^{\bullet-}\right)$ and (5) $\left[\mathrm{C}_{2} \mathrm{mim}^{\bullet}\right]$, as globally described in eqn (9) for the first time. In contrast, at the $\mathrm{Pt}(111)$ electrode, which has been already reported to be less active in acid aqueous solutions for the $\mathrm{CO}_{2}$ electrochemical reduction, ${ }^{34}$ this radical-radical coupling reaction may not take place in $\left[\mathrm{C}_{2} \mathrm{mim}^{+}\right]\left[\mathrm{NTf}_{2}{ }^{-}\right]$, since $-3.1 \mathrm{~V}$ is not a cathodic enough potential for significantly reducing $\mathrm{CO}_{2}$ on $\mathrm{Pt}(111)$ following eqn (1). Thus, the reported coupling reaction by Feroci and co-workers between the electrogenerated carbene and $\mathrm{CO}_{2}$ described in eqn (8) takes place at $\mathrm{Pt}(111)$. However, the imidazolium-2-carboxylate formed is electroinactive and for this reason the peak current at $-0.5 \mathrm{~V}$ decreases in the presence of $\mathrm{CO}_{2}\left(1.1 \mathrm{~mA} \mathrm{~cm}{ }^{-2}\right)$ with respect to the absence of $\mathrm{CO}_{2}$ $\left(1.6 \mathrm{~mA} \mathrm{~cm}{ }^{-2}\right)$, as described by Feroci et al. ${ }^{49,50}$ In contrast, the new $\left[\mathrm{C}_{2} \mathrm{mimH}-\mathrm{CO}_{2}{ }^{-}\right]$adduct described in eqn (9) and formed on $\mathrm{Pt}(110)$ and $\mathrm{Pt}(100)$ is electroactive and may be easily oxidized back to the initial imidazolium cation at $-0.5 \mathrm{~V}$. For this reason, the oxidation peak current for $\mathrm{Pt}(110)$ and $\mathrm{Pt}(100)$ displayed in the inset of Fig. 3 is $2-3$ times larger than the one displayed in the inset of Fig. 2.

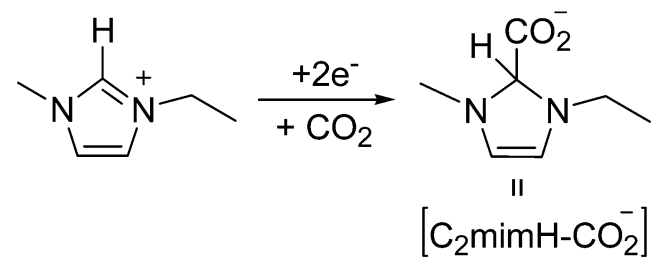

Fig. 4 shows the electrochemical behaviour of 1,3dimethylimidazolium-2-carboxylate on the $\mathrm{Pt}$ polycrystalline electrode as a model carboxylic product of the $\mathrm{CO}_{2}$ coupling reaction reported in eqn (8). Fig. 4 shows the total electroinactivity of that compound within the potential range of interest, from $-0.75 \mathrm{~V}$ to $1.0 \mathrm{~V}$, in agreement with the literature, since the current density displayed in Fig. 4 is negligible in comparison with all other voltammograms and no oxidation or reduction peaks appear. This fact demonstrates that the product generated at $-3.1 \mathrm{~V}$ by simultaneous reduction of $\left[\mathrm{C}_{2} \mathrm{mim}^{+}\right]$and $\mathrm{CO}_{2}$ at $\mathrm{Pt}(110)$ and $\mathrm{Pt}(100)$ electrodes does not

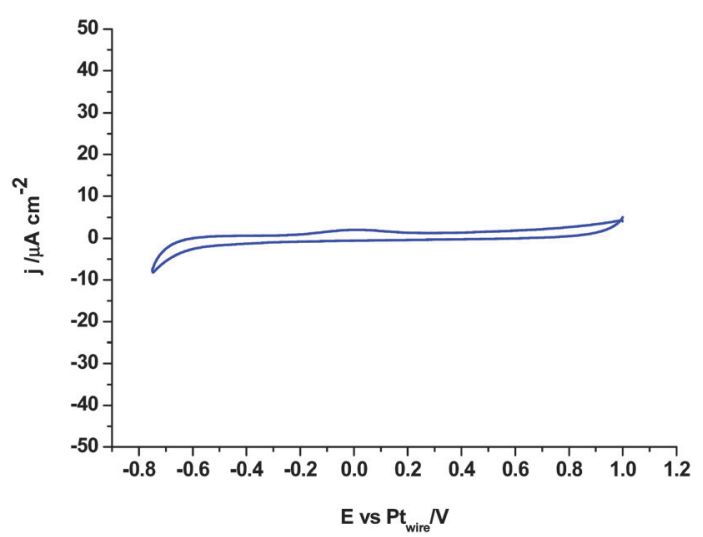

Fig. 4 Cyclic voltammogram of the Pt polycrystalline electrode in argon saturated $\left[\mathrm{C}_{2} \mathrm{mim}^{+}\right]\left[\mathrm{NTf}_{2}{ }^{-}\right]$containing $50 \mathrm{mM}$ 1,3-dimethylimidazolium-2carboxylate. Scan rate: $0.05 \mathrm{~V} \mathrm{~s}^{-1}$.

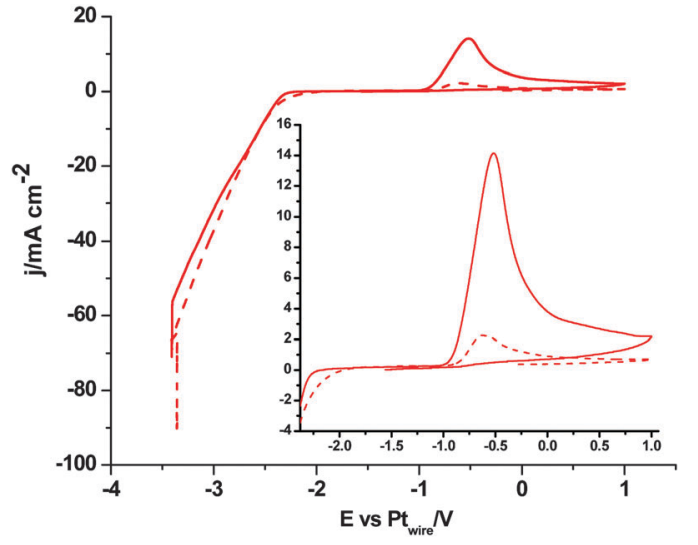

Fig. 5 Linear voltammograms of $\mathrm{Pt}(110)$ in $\left[\mathrm{C}_{2} \mathrm{mim}^{+}\right]\left[\mathrm{NTf}_{2}{ }^{-}\right]$after holding constant the potential at $-3.4 \mathrm{~V}$ for $4 \mathrm{~min}$. Dashed red plot, argon saturated and solid red plot, $\mathrm{CO}_{2}$ saturated solution. Scan rate: $0.05 \mathrm{~V} \mathrm{~s}^{-1}$.

follow eqn (8) and thus, it is not the imidazolium-2-carboxylate derivate already described in the literature.

In order to demonstrate that the formation of that new $\left[\mathrm{C}_{2} \mathrm{mimH}-\mathrm{CO}_{2}{ }^{-}\right]$adduct requires the initial electrochemical reduction of both $\left[\mathrm{C}_{2} \mathrm{mim}^{+}\right]$and $\mathrm{CO}_{2}$, as described in eqn (9) and was never proposed before, Fig. 5 shows a short in situ electrolysis at $-3.4 \mathrm{~V}$ in the presence and the absence of $\mathrm{CO}_{2}$ followed by a linear voltammogram from $-3.4 \mathrm{~V}$ to $1.0 \mathrm{~V}$. The peak current at $-0.5 \mathrm{~V}$ in the argon saturated $\left[\mathrm{C}_{2} \mathrm{mim}^{+}\right]\left[\mathrm{NTf}_{2}{ }^{-}\right]$ does not increase with the electrolysis time (dashed plot in Fig. 5), but in the $\mathrm{CO}_{2}$ saturated $\left[\mathrm{C}_{2} \mathrm{mim}^{+}\right]\left[\mathrm{NTf}_{2}{ }^{-}\right]$the peak current at $-0.5 \mathrm{~V}$ exhibits a constant increase, pointing out a great reversibility of the $\left[\mathrm{C}_{2} \mathrm{mimH}-\mathrm{CO}_{2}{ }^{-}\right]$adduct for releasing back $\left[\mathrm{C}_{2} \mathrm{mim}^{+}\right]$and $\mathrm{CO}_{2}$ under oxidative conditions. Thus, the formation of $\left[\mathrm{C}_{2} \mathrm{mimH}-\mathrm{CO}_{2}{ }^{-}\right]$inhibits radical-radical dimerization reactions to form $\mathrm{C}_{2} \mathrm{O}_{4}{ }^{2-}$ as described in eqn (4) as well as the imidazolium radical dimerization reaction. ${ }^{47,48}$ However, the electrochemical reduction of $\mathrm{CO}_{2}$ under those conditions provokes the electrochemical degradation of the imidazolium based solvent and inhibits further electrochemical reduction of $\mathrm{CO}_{2}$.

Thus, we think that all voltammograms and the in situ electrolysis reported here demonstrate that the $\mathrm{CO}_{2}$ reduction in $\left[\mathrm{C}_{2} \mathrm{mim}^{+}\right]\left[\mathrm{NTf}_{2}{ }^{-}\right]$is blocked after a single electron transfer and the simultaneous degradation of the imidazolium based solvent is produced by the formation of a stable $\left[\mathrm{C}_{2} \mathrm{mimH}-\right.$ $\mathrm{CO}_{2}{ }^{-}$] adduct. Then, a strong acid as a source of free protons, $\left[\mathrm{H}^{+}\right]\left[\mathrm{NTf}_{2}^{-}\right]$, is added into solution to facilitate the electrochemical reduction of $\mathrm{CO}_{2}$ following a 2 electron pathway to form either $\mathrm{HCOOH}\left(\right.$ eqn (2)) ${ }^{36}$ or CO (eqn (3)). ${ }^{42}$ In the absence of $\mathrm{CO}_{2}$, Fig. 6 displays a clear reduction feature at $-1.0 \mathrm{~V}$, corresponding to the reduction of protons to form $\mathrm{H}_{2}$ at the $\mathrm{Pt}(h k l)$ electrode surface and its corresponding reversible oxidation on the reverse potential scan. ${ }^{38}$ This process seems to inhibit the $\left[\mathrm{C}_{2} \mathrm{mim}^{+}\right]$reduction, because no reduction peak is shown at $-0.5 \mathrm{~V}$. Thus, the electrode-RTIL interface has been drastically modified by the presence of a high concentration of available protons, which are preferentially adsorbed and have 


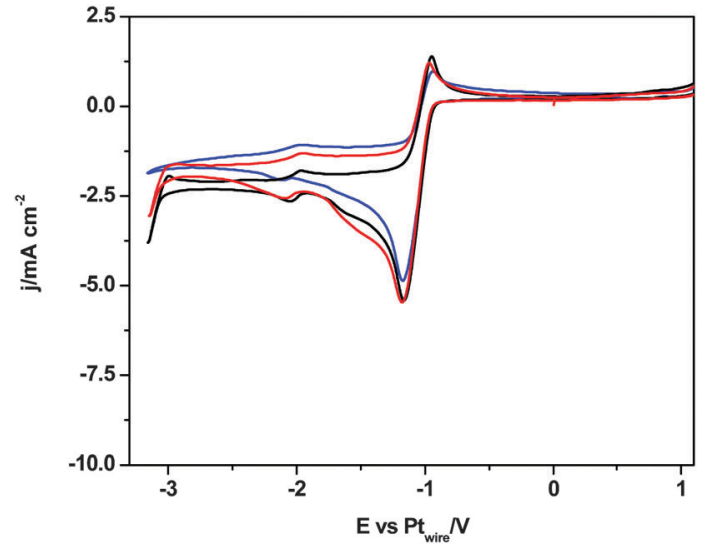

Fig. 6 Cyclic voltammograms of Pt(111), black plot, Pt(110), red plot, and $\mathrm{Pt}(100)$, blue plot. Solution composition $270 \mathrm{mM}\left[\mathrm{H}^{+}\right]\left[\mathrm{NTf}_{2}{ }^{-}\right]$in argon saturated $\left[\mathrm{C}_{2} \mathrm{mim}^{+}\right]\left[\mathrm{NTf}_{2}{ }^{-}\right]$. Scan rate: $0.05 \mathrm{~V} \mathrm{~s}^{-1}$.

displaced the imidazolium cations from the surface of the electrode, catalyzing the proton reduction and inhibiting the $\left[\mathrm{C}_{2} \mathrm{mim}^{+}\right]$reduction.

In contrast, Fig. 7 shows the voltammetric profiles in the presence of dissolved $\mathrm{CO}_{2}$ and protons with different lower potential limits. When the lower potential limit is set at $-2.5 \mathrm{~V}$ (Fig. 7A), no significant changes are observed in the presence of $\mathrm{CO}_{2}$ in solution, which indicates that the $\mathrm{CO}_{2}$ reduction reaction is not taking place. Only when the lower potential limit is set below $-3.0 \mathrm{~V}$, changes in the voltammogram are observed, which indicates that $\mathrm{CO}_{2}$ reduction reaction is taking place. Fig. $7 \mathrm{~B}$ and $\mathrm{C}$ show a new oxidative peak appearing at $0.3 \mathrm{~V}$ (see the inset of Fig. 7B and C), which is univocally linked to the reduction of the $\mathrm{CO}_{2}$ species present in solution, since this peak is absent in an argon saturated solution (Fig. 6). This new oxidation peak does not fit our previous findings on the study of the $\mathrm{CO}$ electrooxidation reaction in $\left[\mathrm{C}_{2} \mathrm{mim}^{+}\right]\left[\mathrm{NTf}_{2}{ }^{-}\right]$, since the $\mathrm{CO}$ oxidation peak appears at more positive potentials. ${ }^{40}$ Furthermore, a very similar peak has been assigned in a recent paper by Compton's group ${ }^{36}$ to the oxidation of the $\mathrm{HCO}_{2} \mathrm{H} /$ $\mathrm{HCO}_{2}{ }^{-}$species formed at a polycrystalline Pt electrode surface after $\mathrm{CO}_{2}$ reduction in $\left[\mathrm{C}_{2} \mathrm{mim}^{+}\right]\left[\mathrm{NTf}_{2}{ }^{-}\right]$. Thus, herein we prove that the electro-synthesis of $\mathrm{HCOOH}$ from $\mathrm{CO}_{2}$ reduction in $\left[\mathrm{C}_{2} \mathrm{mim}^{+}\right]\left[\mathrm{NTf}_{2}^{-}\right]$is a surface sensitive process, since the three different basal planes of $\mathrm{Pt}$ produce different amounts of $\mathrm{HCOOH}$, which is denoted by the different peak area displayed in Fig. 7B and $\mathrm{C}$ and quantified in Table 2. Thus, the results in Table 2 show that the $\mathrm{Pt}(110)$ electrode is the most active basal plane for this reaction and $\mathrm{Pt}(111)$ and $\mathrm{Pt}(100)$ electrodes exhibit a similar low activity (3 times lower than that of the Pt(110) electrode at $-3.5 \mathrm{~V})$.

\section{Conclusions}

We study here the direct electrochemical conversion and recycling of $\mathrm{CO}_{2}$ in one of the most used AILs, $\left[\mathrm{C}_{2} \mathrm{mim}^{+}\right]\left[\mathrm{NTf}_{2}^{-}\right]$, which is mainly hydrophobic and presents a suitable set of physical properties for electrochemical purposes such as
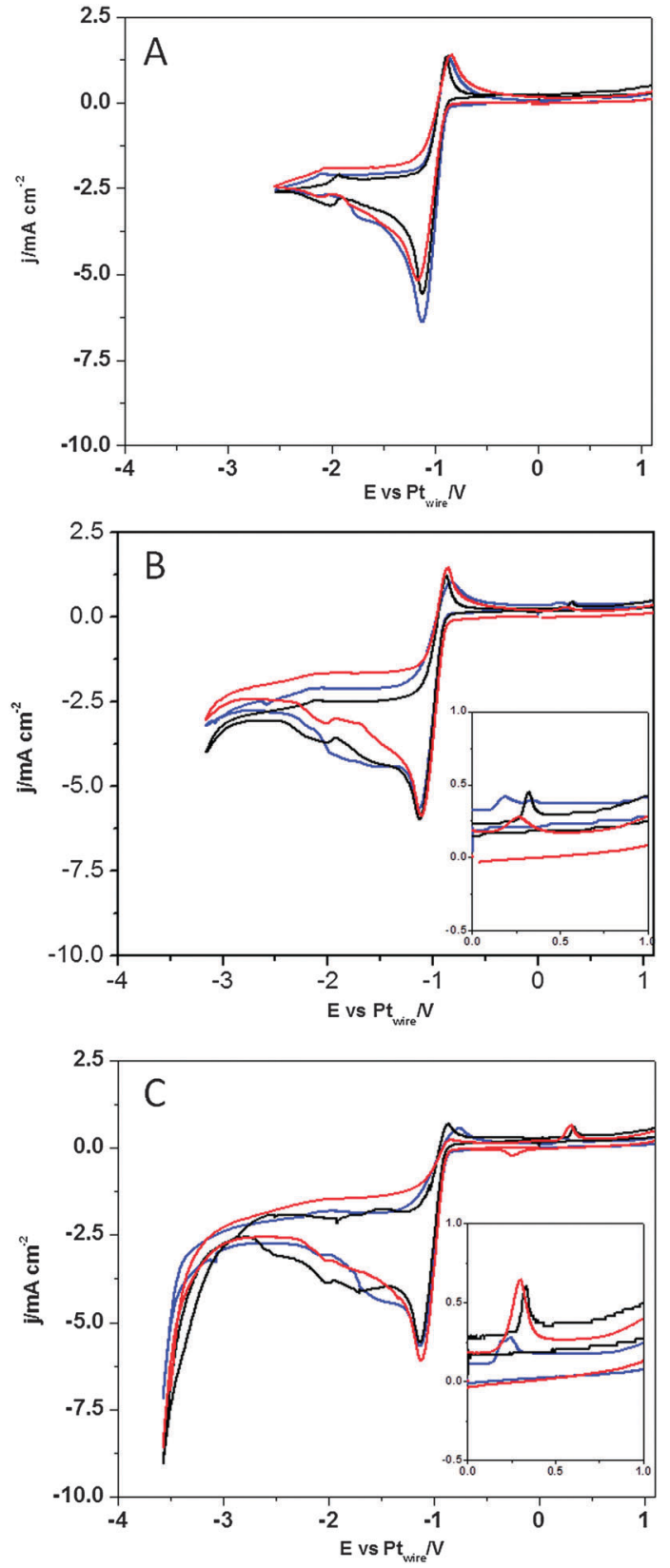

Fig. 7 Cyclic voltammograms of Pt(111), black plot, Pt(110), red plot, and $\mathrm{Pt}(100)$, blue plot. Solution composition $270 \mathrm{mM}\left[\mathrm{H}^{+}\right]\left[\mathrm{NTf}_{2}{ }^{-}\right]$in $\mathrm{CO}_{2}$ saturated $\left[\mathrm{C}_{2} \mathrm{mim}^{+}\right]\left[\mathrm{NTf}_{2}{ }^{-}\right]$. Scan rate: $0.05 \mathrm{~V} \mathrm{~s}^{-1}$. Plots $A, B$ and $C$ represent the same experiment, but reaching a different limit in negative potential: $-2.5 \mathrm{~V}$ for plot $\mathrm{A},-3.1 \mathrm{~V}$ for plot $\mathrm{B}$ and $-3.5 \mathrm{~V}$ for plot $\mathrm{C}$.

Table 2 Charge associated with $\mathrm{HCOOH}$ formed by $\mathrm{CO}_{2}$ reduction, which is quantified by integrating its oxidation peak at $0.3 \mathrm{~V}$ as shown in Fig. 7B and C

\begin{tabular}{llll}
\hline Cathodic & $Q\left(\mu \mathrm{C} \mathrm{cm}^{-2}\right)$ & $Q\left(\mu \mathrm{C} \mathrm{cm}{ }^{-2}\right)$ & $Q\left(\mu \mathrm{Cm}^{-2}\right)$ \\
potential limit $(\mathrm{V})$ & $\operatorname{Pt}(110)$ & $\operatorname{Pt}(111)$ & $\operatorname{Pt}(100)$ \\
\hline-3.1 & 15.4 & 10.8 & 6.22 \\
-3.5 & 46.2 & 14.1 & 12.9 \\
\hline
\end{tabular}

moderate viscosity, high conductivity and high $\mathrm{CO}_{2}$ solubility. Moreover, we use Pt single crystal electrodes, which represent 
the most convenient type of surface structured electrodes for achieving mechanistic information on electrocatalytic reactions.

We propose, for the first time, the formation of a stable adduct $\left[\mathrm{C}_{2} \mathrm{mimH}-\mathrm{CO}_{2}{ }^{-}\right]$by a radical-radical coupling after the simultaneous reduction of $\mathrm{CO}_{2}$ and $\left[\mathrm{C}_{2} \mathrm{mim}^{+}\right]$. It means between the $\mathrm{CO}_{2}$ radical anion and the radical formed from the reduction of the cation $\left[\mathrm{C}_{2} \mathrm{mim}^{+}\right]$. This is especially relevant from a stability point of view, since this reaction provokes the electrochemical degradation of the RTIL employed. So far, only adducts formed by either the reduced form of 1,3-dialkylimidazolium cations (carbene) and $\mathrm{CO}_{2},{ }^{49,50}$ bare RTIL anions and $\mathrm{CO}_{2}{ }^{35}$ or the $\mathrm{CO}_{2}$ radical anion and bare 1,3-dialkylimidazolium cation ${ }^{42}$ were previously reported in the literature. However, radical-radical coupling reactions between two 1,3dialkyl-imidazolium radicals to form a dimer were already reported. ${ }^{47,48}$

We proved by cyclic voltammetry and in situ electrolysis that the reduction of both $\mathrm{CO}_{2}$ and $\left[\mathrm{C}_{2} \mathrm{mim}^{+}\right]$is necessary in order to form the stable adduct $\left[\mathrm{C}_{2} \mathrm{mimH}-\mathrm{CO}_{2}{ }^{-}\right]$. Thus, the formation of such a compound represents an important limitation in the future use of RTILs at the industrial scale, since it represents a new cathodic degradation pathway that limits their successful recycling and the extension of the electrochemical $\mathrm{CO}_{2}$ reduction reaction. Nevertheless, the recyclability of $\left[\mathrm{C}_{2} \mathrm{mim}^{+}\right]\left[\mathrm{NTf}_{2}{ }^{-}\right]$and successful direct $\mathrm{CO}_{2}$ electrochemical reduction are achieved here by adding a proton source $\left[\mathrm{H}^{+}\right]\left[\mathrm{NTf}_{2}^{-}\right]$into solution. The presence of protons in high concentration modifies the electrode-RTIL interface by inhibiting the $\left[\mathrm{C}_{2} \mathrm{mim}^{+}\right]$reduction and favoring the $\mathrm{HCOOH}$ electro-synthesis. Proton abundance avoids $\left[\mathrm{C}_{2} \mathrm{mim}^{+}\right]$from being adsorbed at the Pt electrode surface and blocks its cathodic degradation.

Finally, we continue increasing the use of RTILs as a safe and non-flammable solvent for studying relevant electrocatalytic reactions from an energetic and environmental point of view. Moreover, we demonstrate that the electrochemical reduction of $\mathrm{CO}_{2}$ to form $\mathrm{HCOOH}$ at the Pt $(h k l)$-RTIL interface is considered as a surface sensitive reaction and exhibits the same activity trend as in aqueous acid media, since $\operatorname{Pt}(110)$ is the most active electrode studied.

\section{Acknowledgements}

This work has been partially financed by Generalitat Valenciana through Ayudas para la realización de proyectos de $\mathrm{I}+\mathrm{D}$ para grupos de investigación emergentes (GV/2014/096) and by the MICINN (project CTQ2013-48280-C3-3-R). Dr Hanc-Scherer thanks his former supervisor Prof. Petru Ilea for his advice.

\section{References}

1 T. Faunce, S. Styring, M. R. Wasielewski, G. W. Brudvig, A. W. Rutherford, J. Messinger, A. F. Lee, C. L. Hill, H. deGroot, M. Fontecave, D. R. MacFarlane, B. Hankamer, D. G. Nocera, D. M. Tiede, H. Dau, W. Hillier, L. Wang and R. Amal, Energy Environ. Sci., 2013, 6, 1074-1076.
2 E. V. Kondratenko, G. Mul, J. Baltrusaitis, G. O. Larrazábal and J. Pérez-Ramírez, Energy Environ. Sci., 2013, 6, 3112-3135.

3 T. Sakakura, J.-C. Choi and H. Yasuda, Chem. Rev., 2007, 107, 2365-2387.

4 B. Batanero, F. Barba, C. M. Sánchez-Sánchez and A. Aldaz, J. Org. Chem., 2004, 69, 2423-2426.

5 A. Gennaro, C. M. Sánchez-Sánchez, A. A. Isse and V. Montiel, Electrochem. Commun., 2004, 6, 627-631.

6 Z. Zhang, Y. Xie, W. Li, S. Hu, J. Song, T. Jiang and B. Han, Angew. Chem., Int. Ed., 2008, 47, 1127-1129.

7 G. A. Olah, A. Goeppert and G. K. S. Prakash, J. Org. Chem., 2009, 74, 487-498.

8 F. Sastre, A. V. Puga, L. Liu, A. Corma and H. Garcia, J. Am. Chem. Soc., 2014, 136, 6798-6801.

9 S. C. Roy, O. K. Varghese, M. Paulose and C. A. Grimes, ACS Nano, 2010, 4, 1259-1278.

10 C. Costentin, M. Robert and J.-M. Savéant, Chem. Soc. Rev., 2013, 42, 2423-2436.

11 C. Finn, S. Schnittger, L. J. Yellowlees and J. B. Love, Chem. Commun., 2012, 48, 1392-1399.

12 R. J. Lim, M. Xie, M. A. Sk, J.-M. Lee, A. Fisher, X. Wang and K. H. Lim, Catal. Today, 2014, 233, 169-180.

13 M. Jitaru, D. A. Lowy, M. Toma, B. C. Toma and L. Oniciu, J. Appl. Electrochem., 1997, 27, 875-889.

14 C. M. Sánchez-Sánchez, V. Montiel, D. A. Tryk, A. Aldaz and A. Fujishima, Pure Appl. Chem., 2001, 73, 1917-1927.

15 R. P. S. Chaplin and A. A. Wragg, J. Appl. Electrochem., 2003, 33, 1107-1123.

16 C. M. Sánchez-Sánchez, J. Souza-Garcia, E. Herrero and A. Aldaz, J. Electroanal. Chem., 2012, 668, 51-59.

17 F. Zhou, S. Liu, B. Yang, P. Wang, A. S. Alshammari and Y. Deng, Electrochem. Commun., 2014, 46, 103-106.

18 M. Gattrell, N. Gupta and A. Co, J. Electroanal. Chem., 2006, 594, 1-19.

19 M. Armand, F. Endres, D. R. MacFarlane, H. Ohno and B. Scrosati, Nat. Mater., 2009, 8, 621-629.

20 N. V. Plechkova and K. R. Seddon, Chem. Soc. Rev., 2008, 37, 123-150.

21 Topics in Current Chemistry, Ionic Liquids, ed. B. Kirchner, Springer, Heidelberg, 2010, vol. 290.

22 T. L. Greaves and C. J. Drummond, Chem. Rev., 2008, 108, 206-237.

23 P. Hapiot and C. Lagrost, Chem. Rev., 2008, 108, 2238-2264.

24 C. Cadena, J. L. Anthony, J. K. Shah, T. I. Morrow, J. F. Brennecke and E. J. Maginn, J. Am. Chem. Soc., 2004, 126, 5300-5308.

25 A. M. O'Mahony, D. S. Silvester, L. Aldous, C. Hardacre and R. G. Compton, J. Chem. Eng. Data, 2008, 53, 2884-2891.

26 K. Ohta, M. Kawamoto, T. Mizuno and D. A. Lowy, J. Appl. Electrochem., 1998, 28, 717-724.

27 A. Gennaro, A. A. Isse and E. Vianello, J. Electroanal. Chem., 1990, 289, 203-215.

28 S. S. Moganty and R. E. Baltus, Ind. Eng. Chem. Res., 2010, 49, 5846-5853. 
29 H.-P. Steinrück and P. Wasserscheid, Catal. Lett., 2015, 145, 380-397.

30 Y.-Z. Su, Y.-C. Fu, Y.-M. Wei, J.-W. Yan and B.-W. Mao, ChemPhysChem, 2010, 11, 2764-2778.

31 Y.-Z. Su, Y.-C. Fu, J.-W. Yan, Z.-B. Chen and B.-W. Mao, Angew. Chem., Int. Ed., 2009, 48, 5148-5151.

32 S. Taguchi and A. Aramata, Electrochim. Acta, 1994, 39, 2533-2537.

33 N. Hoshi, S. Kawatani, M. Kudo and Y. Hori, J. Electroanal. Chem., 1999, 467, 67-73.

34 N. Hoshi and Y. Hori, Electrochim. Acta, 2000, 45, 4263-4270.

35 L. L. Snuffin, L. W. Whaley and L. Yu, J. Electrochem. Soc., 2011, 158, F155-F158.

36 B. C. M. Martindale and R. G. Compton, Chem. Commun., 2012, 48, 6487-6489.

37 A. P. Sandoval, J. M. Feliu, R. M. Torresi and M. F. SuárezHerrera, RSC Adv., 2014, 4, 3383-3391.

38 A. M. Navarro-Suárez, J. C. Hidalgo-Acosta, L. Fadini, J. M. Feliu and M. F. Suárez-Herrera, J. Phys. Chem. C, 2011, 115, 11147-11155.

39 A. P. Sandoval, M. F. Suárez-Herrera and J. M. Feliu, Electrochem. Commun., 2014, 46, 84-86.
40 F. A. Hanc-Scherer, C. M. Sánchez-Sánchez, P. Ilea and E. Herrero, ACS Catal., 2013, 3, 2935-2938.

41 C. M. Sánchez-Sánchez, E. Expósito, B. Batanero, V. Montiel, F. Barba and A. Aldaz, Electrochem. Commun., 2004, 6, 595-599.

42 B. A. Rosen, A. Salehi-Khojin, M. R. Thorson, W. Zhu, D. T. Whipple, P. J. A. Kenis and R. I. Masel, Science, 2011, 334, 643-644.

43 V. Climent and J. M. Feliu, J. Solid State Electrochem., 2011, 15, 1297-1315.

44 J. Clavilier, D. Armand, S. G. Sun and M. Petit, J. Electroanal. Chem., 1986, 205, 267-277.

45 J. Clavilier, R. Faure, G. Guinet and R. Durand, J. Electroanal. Chem., 1980, 107, 205-209.

46 Electrochemical Aspects of Ionic Liquids, ed. H. Ohno, John Wiley and Sons, Hoboken, New Jersey, 2005, p. 30.

47 G. H. Lane, Electrochim. Acta, 2012, 83, 513-528.

48 N. De Vos, C. Maton and C. V. Stevens, ChemElectroChem, 2014, 1, 1258-1270.

49 M. Feroci, I. Chiarotto, S. V. Ciprioti and A. Inesi, Electrochim. Acta, 2013, 109, 95-101.

50 M. Feroci, I. Chiarotto, G. Forte and A. Inesi, J. CO2 Util., 2013, 2, 29-34. 